\title{
Science
}

May 2013, Volume 340, Issue 6134, Pages 810-811

Archimer

http://dx.doi.org/10.1126/science.340.6134.811-a

Science. All Rights Reserved.

\section{The True Challenge of Giant Marine Reserves-Response}

\author{
David M. Kaplan ${ }^{1, *}$, Pascal Bach ${ }^{1}$, Sylvain Bonhommeau ${ }^{2}$, Emmanuel Chassot ${ }^{1}$, Pierre Chavance ${ }^{1}$, \\ Laurent Dagorn ${ }^{1}$, Tim Davies ${ }^{3}$, Sibylle Dueri ${ }^{1}$, Rick Fletcher ${ }^{4}$, Alain Fonteneau ${ }^{1}$, \\ Jean-Marc Fromentin ${ }^{2}$, Daniel Gaertner ${ }^{1}$, John Hampton ${ }^{5}$, Ray Hilborn ${ }^{6}$, Alistair Hobday ${ }^{7}$ \\ Robert Kearney ${ }^{8}$, Pierre Kleiber ${ }^{9}$, Patrick Lehodey ${ }^{10}$, Francis Marsac ${ }^{1,11}$, Olivier Maury ${ }^{1,11}$, \\ Chris Mees ${ }^{12}$, Frédéric Ménard ${ }^{1}$, John Pearce ${ }^{12}$, John Sibert $^{13}$
}

\footnotetext{
${ }^{1}$ In stitut de Recherche pour le Développement (IRD), Unité Mixte de Recherche (UMR) 212 Exploited Marine Ecosystems (EME), 34203 Sète cedex, France.

2 (Ifremer), UMR 212 EME, 34203 Sète cedex, France.

3 Imperial College London, Silwood Park Campus, Ascot SL5 7PY, UK.

${ }^{4}$ Department of Fisheries Research, North Beach, WA 6020, Australia.

${ }^{5}$ Oceanic Fisheries Programme, Secretariat of the Pacific Community, 98848 Noumea Cedex, New Caledonia.

${ }_{7}^{6}$ School of Aquatic and Fishery Sciences, University of Washington, Seattle, WA 98195, USA.

7 Commonwealth Scientific and Industrial Research Organisation (CSIRO) Marine and Atmospheric Research, Hobart, Tasmania, 7000, Australia.

${ }^{8}$ Institute for Applied Ecology, University of Canberra, ACT 2601, Australia.

9 U.S. National Marine Fisheries Service (retired), Honolulu, HI 96814, USA.

10 Marine Ecosystems Department, Space Oceanography Division, Collecte Localisation Satellites, 31520 Ramonville Saint-Agne, France.

11 International Centre for Education, Marine and Atmospheric Sciences over Africa, Department of Oceanography, University of Cape Town, Rondebosch 7701, South Africa.

${ }^{12}$ MRAG Ltd, London, W1J 5PN, UK.

13 Joint Institute for Marine and At mospheric Research, University of Hawaii, Honolulu, HI 96822, USA.
}

*: Corresponding author : David M. Kaplan, email address : david.kaplan@ird.fr

\begin{abstract}
A recent News Focus (1) misrepresents several aspects of the potential role of large marine reserves in conserving pelagic species, three of which are addressed here. Tropical tuna stocks in the Indian Ocean are described as "depleted", implying that they are severely overexploited (2). Fishery overcapacity is certainly worrisome, but the available scientific evidence demonstrates that these stocks are not currently overexploited (3). While this clarification by no means precludes appropriate use of area-based management, stock status is central to weighing different management options.
\end{abstract}

The claim that "mainstream marine biologists are more optimistic" about the efficacy of the Chagos Islands reserve because "tuna there don't necessarily swim vast distances" is also misinformed. We note that: 1) juvenile tuna are rarely caught in the Chagos, indicating that Chagos tuna originate elsewhere $(4,5) ; 2)$ an Indian Ocean mark-recapture project $(6,7)$ found average juvenile tuna displacements of over $1150 \mathrm{~km}$, exceeding distances observed in other oceans $(4,6)$; and 3 ) 
"mainstream" scientists with significant publication histories have recently authored independent modeling studies integrating habitat variability and observed movement rates showing that Chagossized reserves have little impact on tuna populations $(8,9)$.

Finally, monitoring is a major challenge, but the example provided - Chagos-only camera surveys - is highly unlikely to identify reserve effects. Control sites and reliable fish movement data are necessary, but will require much larger surveys. Without these, it will be impossible to unequivocally identify as reserve effects observed trends that may well be due to other changes in fishing activity, such as Somali piracy impacts $(10,11)$ and the Indian Ocean time-area closure(12).

Decisions to create large oceanic MPAs for managing pelagic species should use evidence-based evaluations of potential benefits prior to implementation followed by careful estimation of their efficacy rather than relying on square kilometers tallies(13). That is the true "challenge" of giant marine reserves.

\section{References:}

1. C. Pala, Giant Marine Reserves Pose Vast Challenges, Science 339, 640-641 (2013).

2. The glossary of the UN Food \& Agriculture Organisation (FAO) defines "depleted stock" as a stock driven by fishing to a very low level of abundance compared to historical levels, with dramatically reduced spawning biomass and reproductive capacity (available at http://www.fao.org/fi/glossary/spec-term-n.asp?id_glo=832\&id_lang=TERMS_E).

3. M. J. Juan-Jordá, I. Mosqueira, A. B. Cooper, J. Freire, N. K. Dulvy, Global population trajectories of tunas and their relatives, Proceedings of the National Academy of Sciences (2011), doi:10.1073/pnas.1107743108.

4. D. M. Kaplan et al., Potential consequences of pelagic marine protected areas: Insight from Indian Ocean tropical tuna fisheries, Fish and Fisheries (submitted).

5. Historical Chagos purse-seine juvenile catch of major tropical tunas represents just $0.6 \%$ of the Indian Ocean total, and juveniles represent only $0.5 \%$ of the Chagos purse-seine catch biomass. By comparison, historical catch in the Somalia EEZ is $4 \%$ juvenile (by mass), and $\sim 22$ times more juvenile biomass is caught in the Somali EEZ than in the Chagos ( 17 times the catch-per-unit-area).

Calculations are based on publicly available IOTC catch data from the period 1993-2004, the last year fishing agreements were in place for the Somalia EEZ. In terms of total catch, Chagos represents approximately $1.5 \%$ and $0.5 \%$ of total Indian Ocean purse-seine and longline catch, respectively.

6. J.-P. Hallier, J. Million, The Indian Ocean Tuna Tagging Programme (2012) (available at http://www.iotc.org/files/proceedings/2012/sym/02_PSym.pdf).

7. The regional tuna tagging program of the Indian Ocean (RTTP-IO) tagged over 168,000 skipjack and (primarily juvenile) yellowfin and bigeye tuna over the period 2002-2009. Approximately 30,000 of those tags have been recovered to date.

8. J. Sibert, I. Senina, P. Lehodey, J. Hampton, Shifting from marine reserves to maritime zoning for conservation of Pacific bigeye tuna (Thunnus obesus), Proceedings of the National Academy of Sciences (2012), doi:10.1073/pnas.1209468109.

9. S. Dueri, O. Maury, Modelling the effect of marine protected areas on the population of skipjack tuna in the Indian Ocean, Aquatic Living Resources (2012), doi:10.1051/alr/2012032. 
10. E. Chassot et al., Analysis of the effects of Somali piracy on the European tuna purse seine fisheries of the Indian Ocean (Indian Ocean Tuna Commission, Victoria, Seychelles, 2010; http://www.iotc.org/files/proceedings/2010/sc/IOTC-2010-SC-09.pdf), p. 26.

11. F. Marsac, Impacts of piracy threats in the West Indian Ocean on the activity and yield of the longline and purse seine fisheries (Indian Ocean Tuna Commission, Victoria, Seychelles, 2009; http://www.iotc.org/files/proceedings/2009/sc/IOTC-2009-SC-10\%5BE\%5D.pdf), p. 10.

12. IOTC, For the Conservation and Management of Tropical Tunas Stocks in the IOTC Area of Competence (Indian Ocean Tuna Commission, 2010;

http://www.iotc.org/files/CMM/Resolution\%2010-01.pdf), p. 5.

13. N. C. Ban et al., Systematic Conservation Planning: A new recipe for managing the High Seas, Conservation Letters (in press), doi:10.1111/conl.12010. 